\title{
Sosyoekonomik Durumun Öğrenci Başarısına Etkisi (7. Sınıf Türkçe ve Fen Bilimleri
}

\section{Dersleri Örneklemi)}

\section{Yasin KILIÇ, Mehmet Akif HAŞILOĞLU*}

Öz: $\mathrm{Bu}$ çalışmanın amacı, Ağrı ölçeğinde ortaokul 7. sınıfta okuyan öğrencilerin sosyoekonomik durumları ile Türkçe ve Fen Bilimleri derslerindeki akademik başarı düzeyleri arasında anlamlı bir ilişkinin olup olmadığını belirlemektir. Buna göre, öğrenci ebeveynlerinin gelir durumları ve öğrenim düzeyleri ile öğrencilerin cinsiyetleri, anasınıfına gitme durumları, kardeş sayıları, bilgisayara sahip olma durumları, sosyoekonomik değişkenler olarak belirlendi. Bu değişkenler ile öğrencilerin Türkçe ve Fen Bilimleri derslerinden aldıkları puanlar arasında anlamlı bir ilişkinin olup olmadığının tespitine çalışıldı.

Araştırma 2016-2017 eğitim-öğretim yılında güz döneminde Ağrı ili merkez ilçedeki 3 ortaokulda gerçekleştirilmiştir. Öğrencilerin sosyoekonomik durumları ile Türkçe ve Fen Bilimleri derslerindeki başarı düzeylerinin tespiti için 13 maddelik bir anket formu hazırlanmış ve bu anket formu 7. sınıfta okuyan 396 öğrenciye uygulanmıştır.

Anketten elde edilen bulgular, SPSS 16.0 ile analiz edilmiş, öğrencilerin anket maddelerine verdikleri cevaplar, frekans ve yüzde olarak hesaplanmıştır. Bu cevapların bağımsız değişkenlere göre anlamlılığının belirlenmesi için "Mann Whitney U, Kruskal Wallis H ve korelasyon testleri” kullanılmıştır.

\footnotetext{
*Ağrı İbrahim Çeçen Üniversitesi Eğitim Fakültesi Türkçe ve Sosyal Bilimler Eğitimi Bölümü, Ağrı ykilic@agri.edu.tr

* Ağrı İbrahim Çeçen Üniversitesi Eğitim Fakültesi Matematik ve Fen Bilimleri Eğitimi Bölümü, Ağrı mehmet.hasiloglu@hotmail.com
} 
Araştırmadan elde edilen bulgulara ve bunların analizine bakıldığında genel olarak öğrencilerin sosyoekonomik durum değişkenleri (bağımsız değişkenler) ile Türkçe ve Fen Bilimleri dersleri başarı puanları (bağımlı değişkenler) arasında kuvvetli bir ilişkinin bulunduğu ve bu bağımlı ve bağımsız değişkenlerin anlamlı düzeyde farklılaştığı görülmektedir.

Anahtar Kavramlar: Sosyoekonomik, dil öğretimi, Eğitim, Türkçe eğitimi, Fen eğitimi

The Effect of Socioeconomic Status on Student Achievement: The Case of 7th Grade Turkish and Science Courses

\begin{abstract}
This study aims to examine whether there is a significant relationship between the socioeconomic status of 7 th grade students attending middle schools in Ağr1 and their achievement in Turkish and Science and Technology courses. To this end, income and education levels of students' parents, students' gender, whether they attended a kindergarten, the number of siblings they have and whether they own a computer were identified as the socioeconomic variables. We then examined whether there were significant relationships between these variables and the grades students received from Turkish and Science courses.
\end{abstract}

The study was conducted in the three middle schools in the central district of Ağrı province, during the Fall semester of the 2016-2017 academic year. A 13item questionnaire was developed to identify students' socioeconomic status and the achievement in Turkish and Science courses, and this questionnaire was administered to 396 seventh grade middle school students. 
Data collected via the questionnaire were analyzed using SPSS 16.0, and frequencies and percentages of student responses were calculated. To identify whether these responses were significantly related to the independent variables, we used Mann Whitney U, Kruskal Wallis H and correlation tests.

Our analysis showed that overall, there was a strong relationship between socioeconomic status variables (independent variables) and grades for Turkish and Science courses, and these two groups of dependent and independent variables varied significantly.

Keywords: Socioeconomic status, language instruction, education, Turkish, science education

\section{Giriş}

Eğitim bireyde istenen davranış değişikliğini gerçekleştirme sürecidir. Pek çok faktör eğitim sürecini doğrudan veya dolaylı olarak etkilemektedir. Bu faktörler bireysel, sosyal, ekonomik şekilde çeşitlilik arz eder. Dolayısı ile eğitimi soyut bir kavram olarak değil; bireyin bütün hayatını kuşatan bir olgu, bir gerçeklik olarak düşünmek gerekir. Bireyin gerek psikolojik, gerek ekonomik, gerekse sosyal olarak ilerlemesinde eğitim başat rol oynamaktadır. Bireyin eğitimi; ona istendik davranışın ve bilgilerin sağlıklı bir şekilde öğretilmesi ve bu edinimlerin birey tarafından özümsenmesiyle ile gerçekleşir (Kırkkılıç ve Maden, 2009: 1424). Bireye yönelik etkin bir eğitim vermenin ve öğrencilerin derse yönelik olumlu tutum geliştirmelerini sağlamanın en etkili yollarından biri de onlar için uygun öğretim yöntemini uygulamaktır (Tüzemen,T. ve Kardaş, M.N. 2016: 129). 
Örneğin, ekonominin ihtiyaç duyduğu insan gücünün yetiştirilmesi, eğitim hizmetlerinin yürütülmesi, topluma yönelik üretim araçlarının geliştirilmesi, ekonomik arz ve talebin oluşturulması, ekonomik verimliliğin arttırılması vb. ancak eğitsel faaliyetlerle gerçekleştirilebilir. Aynı şekilde birey ve toplumun sosyal olarak ilerlemesi ve sosyal ihtiyaçlarının karşılanması vb. ancak eğitsel çalışmalarla mümkündür. Dolaysıyla hem toplumsal hem de ekonomik alanı ve bu iki alan arasındaki ilişkileri, bireyin sosyal ve ekonomik açıdan sahip olduğu özellikleri belirtmek için kullanılan sosyoekonomik kavramını, eğitimle birlikte düşünmek gerekir (Yılmaz, 1995: 55). Bazı sosyoloji araştırmalarında bireyin sosyoekonomik özellikleri kavramı, genel olarak bireyin öğrenim düzeyi, gelir düzeyi, mesleği için vb. kullanılmışıı (Kessler, 1985: 131).

Dil eğitimi ve fen bilimleri eğitimi alanda yapılan çeşitli çalışmalar, öğrencilerin akademik başarılarında sosyoekonomik özelliklerin etkili olduğunu göstermektedir:

$\mathrm{Bu}$ özellikler, öğrencinin bulunduğu ilin gelişmişlik düzeyi, ailesinin sosyoekonomik durumu, kişisel özellikleri, onun öğrenim gördüğü okulu ya da sınıfı olabilir. Bu yüzden öğrencinin akademik başarısı ile ilişkili olabilecek bu özellikleri birlikte ele almak gerekir. Ayrıca öğrencilerin özel ders alma, özel okula veya dershaneye gitme durumuyla, ailedeki kişi sayısı, ev olanakları öğrencilerin başarıları üzerinde etkili olmaktadır (Güvendir, M. A. 2014: 165)

\section{Araştırmanın Amacı}

$\mathrm{Bu}$ araştırmanın amacı, 7. sınıf öğrencilerinin sosyoekonomik durumları ile Türkçe ve Fen Bilimleri derslerindeki başarıları arasında bir ilişkinin olup olmadığını belirlemektir. Bu amaç doğrultusunda çalışmanın problem cümlesi, “Ortaokul 7. sınıfta okuyan öğrencilerin sosyoekonomik durumları ile Türkçe ve Fen Bilimleri derslerindeki akademik başarı 
düzeyleri arasında nasıl bir ilişki vardır?” şeklinde düzenlenmiştir. Bu problemden hareketle aşağıdaki alt problemlere cevaplar aranmıştır:

1. Öğrencilerin cinsiyetleri ile Türkçe ve Fen Bilimleri derslerindeki akademik başarıları arasında bir ilişki var mıdır?

2. Öğrencilerin bilgisayara sahip olma durumları ile Türkçe ve Fen Bilimleri derslerindeki akademik başarıları arasında bir ilişki var mıdır?

3. Öğrencilerin dershaneye (kursa) ve ana sınıfına gitme durumları ile Türkçe ve Fen Bilimleri derslerindeki akademik başarıları arasında bir ilişki var mıdır?

4. Öğrencilerin kardeş sayılar ve kitap okuma durumları ile Türkçe ve Fen Bilimleri derslerindeki akademik başarıları arasında bir ilişki var mıdır?

5. Öğrencilerin ebeveynlerinin öğrenim durumları ile Türkçe ve Fen Bilimleri derslerindeki akademik başarıları arasında bir ilişki var mıdır?

6. Öğrenci velilerinin meslekleri ve gelir durumları ile Türkçe ve Fen Bilimleri derslerindeki akademik başarıları arasında bir ilişki var mıdır?

7. Öğrencilerin Türkçe dersindeki akademik başarıları ile Fen Bilimleri dersindeki akademik başarıları arasında bir ilişki var mıdır?

\section{Yöntem}

$\mathrm{Bu}$ çalışmanın yöntem kısmında araştırma deseni, çalışma grubu, veri toplama araçları, verilerin analizi ve araştırmada kullanılan istatistik tekniklerinin açıklanması gibi başl1k ve konulara yer verilmiştir. 
Araştırma Deseni: $\mathrm{Bu}$ araştırmada genel tarama modellerinden faydalanılmış, saha çalışması yapılmış ve betimsel yöntemler uygulanmıştır. Genel tarama modeli, evren hakkında bir yargıya ulaşmak için evrenin tamamı veya ondan alınacak örneklem üzerinde yapılan tarama düzenlemeleridir (Karasar, 2014: 79). Betimsel yöntemler ise araştırılan problemi tespit etmektir.

Çalışma Grubu: Bu araştırmanın çalışma evreni Ağrı ili olup, araştırma 2016-2017 eğitim-öğretim yılının birinci döneminde, Ağrı ili merkez ilçedeki Kuva-i Milliye, İMKB Gazi ve Cumhuriyet ortaokullarında gerçekleştirilmiştir. Bu ortaokulların belirlenmesinde, ilgili okulların sosyoekonomik düzeylerinin zayıf, orta ve iyi olma durumları rol oynamıştır. Veri toplamak için hazırlanan ölçek (anket soruları) 7. sınıf öğrencilerinden rast gele yöntemle belirlenen öğrencilere uygulanmıştır. Araştırmanın örneklemini toplam 396 öğrenci oluşturmuştur.

Veri Toplama Araçları: Bu araştırma betimsel bir çalışmadır. Çalışmada veri toplama aracı olarak anket kullanılmıştır. Anketler örneklem grubuna elden ulaştırılarak uygulanmış ve toplanmıştır. Ortaokul 7. sınıf öğrencilerine yönelik anket soruları hazırlanırken iki öğretim üyesinin görüşü alınmış, ayrıca daha önce hazırlanan anket sorularından yararlanılmıştır (Köse, 2011; Gelbal, 2008). Böylece anket sorularının geçerliği sağlanmıştır.

$\mathrm{Bu}$ çalışmada veri toplama aracı olarak olgusal sorular kullanılmıştır. $\mathrm{Bu}$ veriler araştırmacının yorum ve değerlendirmesini gerektirmeyen, kişisel yargılardan bağımsız, üzerinde herkesin anlaşabileceği türden gerçeklerdir (yaş, cinsiyet, meslek vb.) (Yazıcıoğlu \& Erdoğan, 2004: 56-57). Bu tarz soruların cevapları üzerine güvenilirlik analizi uygulanamamaktadır. Dolayısıyla bu tür sorularda güvenirlik analizi uygulanmamıştır. 
Anket ölçeği 13 maddeden oluşmaktadır. Bu ölçek, öğrencilerin sosyoekonomik durumlarıyla Türkçe ve Fen Bilimleri derslerinden aldıkları puanları belirlemek için hazırlanmıştır. Anketin ilk 4 maddesinin cevapları iki seçenekli olarak hazırlanmıştır: $\mathrm{Bu}$ maddeler, öğrencilerin cinsiyetleri, bir bilgisayara sahip olup olmama, dershane (kurs) ve ana sınıfına gidip gitmeme gibi durumlarıyla ilgilidir. Bu soruların evet, var gibi olumlu cevapları (2); hayır, yok gibi olumsuz cevapları ise (1) şeklinde derecelendirilmiştir.

Anket ölçeği, 5. maddeden itibaren 3'lü seçenekler şeklinde derecelendirilmiştir. Öğrencilerin yaşadıkları evlerin oda sayısıyla ilgili 5. madde 1-2 oda (1), 3 oda (2), 4 ve üstü oda (3) şeklinde; öğrencilerin kardeş sayıları ile ilgili 6. madde ise 0-1 (1), 2-3 (2), 4 ve üstü (3) şeklinde derecelendirilmiştir. Ölçeğin 7. maddesi öğrencilerin bir dönem boyunca okudukları kitap sayısıyla ilgili olup; ayda 1 kitap (3), 2-3 ayda 1 kitap (2), 4 ay ve üstü 1 kitap veya hiç okumam (1) şeklindedir. Ölçeğin 8. maddesi öğrenci annelerinin, 9. maddesi ise öğrenci babalarının öğrenim durumları ile ilgili olup, okur-yazar değil veya ilkokul (1), ortaokul (2), lise ve üniversite (3) şeklinde derecelendirilmiştir.

Ölçekteki 10. madde öğrenci velilerinin meslekleriyle ilgili olup, derecelendirmede ailelerin sosyoekonomik durumları göz önünde bulundurulmuştur. Buna göre, işsiz, çiftçi ve işçi (1), memur (2), esnaf, serbest meslek, (diğeri...) (3) şeklinde derecelendirilmiştir. Öğrenci ailelerinin gelir düzeyleri, 2016 asgari ücreti, en düşük düzeydeki devlet memuru maaşı ve üstü göz önünde bulundurulmuştur. Böylece aile gelir düzeyleri ile ilgili olan 11. madde, az: 0-1404 TL (1), orta: 1405-2029 (2), iyi: 2030 ve üstü-(3) şeklinde derecelendirilmiştir.

Bu araştırmada, ortaokul 7. sınıfta okuyan öğrencilerin 2016-2017 eğitim- öğretim yılı 1. dönem Türkçe ve Fen Bilimleri derslerinden aldıkları karne puanları, veri olarak kullanılmış, öğrencilerin her iki dersten aldıkları puanlar, öğrencilerin ilgili derslerdeki 
başarılarını ölçmede yeterli görülmüştür. Anketin 12. ve 13. maddelerinde öğrencilerin her iki dersten aldıkları puanların aralığı zayıf: 0-2 (1) orta:3 (2), iyi:4-5 (3) şeklindedir. Bu maddelerdeki puan aralığının belirlenmesinde Milli Eğitim Bakanlığı ortaokullar öğrenci başarısını değerlendirme ölçeği olan 5'li not sistemi esas alınmıştır (MEB, yönetmelik, 2013: $15)$.

Parametrik olmayan testlerde bir tablodaki 5'ten küçük teorik değere sahip göz sayısı, toplam göz sayısının \% 20'sini aşarsa tablonun sıra ya da sütunlarında uygun birleştirme yapmak gerekir (Özdamar, 1999: 344). Bu kurala göre, anketin bazı maddelerinde uygun birleştirmeler yapılmıştır.

Ölçekte yer alan ifadelerin düzey aralığ1 1'den 3'e kadar derecelendirilmiştir. Puanlamada kullanılan 1, 2 ve 3 derecelendirme rakamları olumsuzdan olumluya doğru bir seyir takip etmiştir. Yani 1 az (zayıf), 2 orta, 3 ise iyi kavramını ifade etmektedir. Buna göre oluşturulan ölçekte gözlenme sıklığı ve bunların sınır değerleri aşağıda gösterilmiştir.

Tablo 1: Anket verilerinin derecelendirilmesinde esas alınan verilerin ağırlı̆̆l ve aritmetik ortalama aralıkları

\begin{tabular}{c|c|c}
\hline Verilen Ağırlık & Aritmetik Ortalama Aralıkları & Katılma Düzeyi \\
\hline 3 & $2.33-3.00$ & İyi \\
\hline 2 & $1.67-2.32$ & Orta \\
\hline 1 & $1.00-1.66$ & $\mathrm{Az}$ \\
\hline
\end{tabular}

Anketin ilk 11 maddesi araştırmada bağımsız değişkenler olarak, öğrencilerin Türkçe ve Fen Bilimleri puanlarını gösteren son iki madde ise bağımlı değişken olarak belirlenmiştir.

Verilerin Analizi: Bulgular, SPSS 16.0 ile analiz edilmiş, öğrencilerin anket maddelerine verdikleri cevaplar frekans ve yüzde olarak hesaplanmıştır. 
Örneklem grubuna uygulanan ölçeğin değerleri normal bir dağılım göstermemiştir. Böylece araştırmada parametrik testler varsayımları karşılamadığı için parametrik olmayan testler uygulanmıştır.

Uygulama: Araştırma 2016-2017 eğitim-öğretim yılının birinci döneminde, Ağrı ilindeki üç ortaokulda uygulanmıştır. Bu bölümde öğrencilerin sosyoekonomik durumları ile Türkçe ve Fen Bilimleri puanları arasındaki ilişkiyi belirlemek için Mann-Whitney U Testi ve Kruskal Wallis H-Testi uygulanmıştır. Öğrencilerin Türkçe ve Fen Bilimleri dersleri başarı düzeyleri arasındaki ilişkiyi belirlemek için ise korelasyon testi uygulanmıştır.

\section{Bulgular}

Tablo 2: Öğrencilerin sosyoekonomik durumlart ile Türkçe ve Fen Bilimleri puanlarına ilişkin Mann-Whitney U Testi Sonuçları

\begin{tabular}{|c|c|c|c|c|c|c|c|}
\hline \multirow[t]{5}{*}{$\begin{array}{l}\text { 1.Öğrencilerin } \\
\text { cinsiyetleri }\end{array}$} & & & $\mathrm{N}$ & $\%$ & $\bar{X}$ & $\begin{array}{l}\text { Mann- } \\
\text { Whitney U }\end{array}$ & $\mathrm{P}$ \\
\hline & \multirow{2}{*}{$\begin{array}{l}\text { Türkçe } \\
\text { puanları }\end{array}$} & $\mathrm{K}_{1 \mathrm{Z}}(1)$ & 196 & 49,5 & 201,57 & \multirow[t]{2}{*}{18998,000} & \multirow[t]{2}{*}{,569 } \\
\hline & & Erkek (2) & 200 & 50,5 & 195,49 & & \\
\hline & \multirow{2}{*}{$\begin{array}{l}\text { Fen } \\
\text { Bilimleri } \\
\text { puanlar1 }\end{array}$} & $\mathrm{K}_{1 \mathrm{z}}(1)$ & 196 & 49,5 & 204,49 & \multirow[t]{2}{*}{18425,000} & \multirow[t]{2}{*}{,261 } \\
\hline & & Erkek (2) & 200 & 50,5 & 192,63 & & \\
\hline \multirow{4}{*}{$\begin{array}{l}\text { 2. Öğrencilerin } \\
\text { bilgisayara sahip } \\
\text { olma durumu }\end{array}$} & \multirow{2}{*}{$\begin{array}{l}\text { Türkçe } \\
\text { puanları }\end{array}$} & Hayır (1) & 231 & 58,3 & 165,92 & \multirow[b]{2}{*}{11532,500} & \multirow[b]{2}{*}{,000 } \\
\hline & & Evet (2) & 165 & 41,7 & 244,11 & & \\
\hline & \multirow{2}{*}{$\begin{array}{l}\text { Fen } \\
\text { Bilimleri } \\
\text { puanlar1 }\end{array}$} & Hayır (1) & 231 & 58,3 & 178,22 & \multirow[t]{2}{*}{14373,000} & \\
\hline & & Evet (2) & 165 & 41,7 & 226,89 & &, 000 \\
\hline \multirow{4}{*}{$\begin{array}{l}\text { 3. Ö ğrencilerin } \\
\text { dershaneye } \\
\text { (kursa) gitme } \\
\text { durumu }\end{array}$} & \multirow{2}{*}{$\begin{array}{l}\text { Türkçe } \\
\text { puanları }\end{array}$} & Hayır (1) & 275 & 69,4 & 173,08 & \multirow[b]{2}{*}{9646,500} & \multirow[b]{2}{*}{,000 } \\
\hline & & Evet (2) & 121 & 30,6 & 256,28 & & \\
\hline & \multirow{2}{*}{$\begin{array}{l}\text { Fen } \\
\text { Bilimleri } \\
\text { puanları }\end{array}$} & Hayır (1) & 275 & 69,4 & 173,08 & \multirow[t]{2}{*}{9669,500} & \multirow[t]{2}{*}{,000 } \\
\hline & & Evet (2) & 121 & 30,6 & 256,28 & & \\
\hline
\end{tabular}




\begin{tabular}{|c|c|c|c|c|c|c|c|}
\hline \multirow{4}{*}{$\begin{array}{l}\text { 4. Öğrencilerin } \\
\text { ana sınıfına gitme } \\
\text { durumu }\end{array}$} & \multirow{2}{*}{$\begin{array}{l}\text { Türkçe } \\
\text { puanları }\end{array}$} & Hayır (1) & 198 & 50,0 & 215,20 & \multirow[b]{2}{*}{16294,500} & \multirow[b]{2}{*}{,002 } \\
\hline & & Evet (2) & 198 & 50,0 & 181,80 & & \\
\hline & \multirow{2}{*}{$\begin{array}{l}\text { Fen } \\
\text { Bilimleri } \\
\text { puanları }\end{array}$} & Hayır (1) & 198 & 50,0 & 215,29 & \multirow[t]{3}{*}{16278,500} & \multirow[t]{3}{*}{,001 } \\
\hline & & Evet (2) & 198 & 50,0 & 181,71 & & \\
\hline Toplam & & & 396 & 100,0 & & & \\
\hline
\end{tabular}

Tablo 2’de öğrencilerin cinsiyetleri, bilgisayara sahip olma durumları, ana sınıfına ve dershaneye (kursa) gitme durumları bağımsız değişken olarak, öğrencilerin Türkçe ve Fen Bilimleri derslerinden aldıkları puanlar ise bağımlı değişken olarak değerlendirilmiştir. Bağımlı değişkenler ile bağımsız değişkenlerin arasında anlamlı bir ilişkinin bulunup bulunmaması için Man Withney U testi uygulanmıştır. Bu tabloya göre örneklem grubunu oluşturan öğrencilerin \%49,5’i k1z, \%50,5’i ise erkektir. Tablodaki sonuçlara göre, öğrencilerin Türkçe $(\mathrm{p}=569>0,05)$ ve Fen Bilimleri $(\mathrm{p}=569>0,05)$ derslerindeki akademik başarıları ile cinsiyetleri arasında anlamlı bir farklılık yoktur.

Tabloya göre araştırmaya katılan öğrencilerden \%58,3’ü bir bilgisayara sahipken \%41,7'si ise bir bilgisayara sahip değildir. Bu öğrencilerden \%69,4'ü dershane veya özel bir kursa gitmiş, \%50'si ise ana sınıfa gitmiştir. Diğerleri ise ilgili kurumlara gitmemiştir. Araştırmanın bu bölümünde uygulanan Man Withney U testine göre, öğrencilerin Türkçe ve Fen Bilimleri derslerindeki başarıları ile ana sınıfına, dershaneye (kursa) gitme durumları ve bir bilgisayara sahip olmaları arasında olumlu yönde anlamlı bir farklılık bulunmaktadır. $\mathrm{Bu}$ anlamlılık değeri 0,000 ile 00,2 arasında değişmektedir. Yani bir bilgisayara sahip olan, ana sınıfına ve özel bir kursa devam eden öğrenciler diğer öğrencilere göre Türkçe ve Fen Bilimleri derslerinde daha başarılıdır. 
Tablo 3: Öğrencilerin sosyoekonomik durumları ile Türkçe ve Fen Bilimleri puanlarına ilişkin Kruskal Wallis H-Testi I

\begin{tabular}{|c|c|c|c|c|c|c|c|}
\hline \multirow{4}{*}{$\begin{array}{l}\text { Türkçe } \\
\text { puanları }\end{array}$} & & & $\mathrm{N}$ & $\%$ & $\bar{X}$ & $\begin{array}{l}\text { Kruskal Wallis } \\
\text { H-Testi }\end{array}$ & $\mathrm{P}$ \\
\hline & \multirow{6}{*}{ 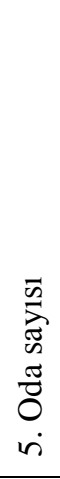 } & 1 & 118 & 29,8 & 185,98 & \multirow{3}{*}{$\begin{array}{l}\mathrm{X}^{2}: 2,872 \\
\mathrm{sd}: 2\end{array}$} & \multirow[t]{3}{*}{,238 } \\
\hline & & 2 & 229 & 57,8 & 205,97 & & \\
\hline & & 3 & 49 & 12,4 & 193,74 & & \\
\hline \multirow{3}{*}{$\begin{array}{l}\text { Fen } \\
\text { Bilimleri } \\
\text { puanları }\end{array}$} & & 1 & 118 & 29,8 & 188,19 & \multirow[t]{3}{*}{$X^{2}: 1,620$} & \multirow[t]{3}{*}{,445 } \\
\hline & & 2 & 229 & 57,8 & 203,03 & & \\
\hline & & 3 & 49 & 12,4 & 202,16 & & \\
\hline \multirow{3}{*}{$\begin{array}{l}\text { Türkçe } \\
\text { puanları }\end{array}$} & \multirow{6}{*}{ 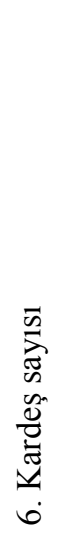 } & 1 & 59 & 14,9 & 251,08 & \multirow[t]{3}{*}{$X^{2}: 195,245$} & \multirow[t]{3}{*}{, 000} \\
\hline & & 2 & 161 & 40,7 & 270,05 & & \\
\hline & & 3 & 176 & 44,4 & 115,43 & & \\
\hline \multirow{3}{*}{$\begin{array}{l}\text { Fen } \\
\text { Bilimleri } \\
\text { puanları }\end{array}$} & & 1 & 59 & 14,9 & 232,71 & \multirow[t]{3}{*}{$X^{2}: 94,615$} & \multirow[t]{3}{*}{,000 } \\
\hline & & 2 & 161 & 40,7 & 248,46 & & \\
\hline & & 3 & 176 & 44,4 & 141,33 & & \\
\hline \multirow{3}{*}{$\begin{array}{l}\text { Türkçe } \\
\text { puanları }\end{array}$} & \multirow{6}{*}{ 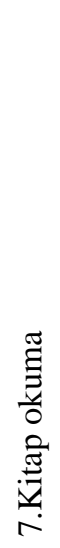 } & 1 & 145 & 36,6 & 92,96 & \multirow[t]{3}{*}{$X^{2}: 268,933$} & \multirow[t]{3}{*}{, 000} \\
\hline & & 2 & 151 & 38,1 & 223,72 & & \\
\hline & & 3 & 100 & 25,3 & 313,46 & & \\
\hline \multirow{3}{*}{$\begin{array}{l}\text { Fen } \\
\text { Bilimleri } \\
\text { puanları }\end{array}$} & & 1 & 145 & 36,6 & 130,93 & \multirow{3}{*}{$\begin{array}{l}X^{2}: 127,868 \\
\text { sd: } 2\end{array}$} & \multirow[t]{3}{*}{,000 } \\
\hline & & 2 & 151 & 38,1 & 206,32 & & \\
\hline & & 3 & 100 & 25,3 & 284,67 & & \\
\hline Toplam & & & 396 & 100,0 & & & \\
\hline
\end{tabular}

Tablo 3'te görüldüğü üzere, öğrencilerin evlerindeki oda sayısı, kardeş sayıları ve bir dönem boyunca okuduğu kitap sayısı bağımsız değişkenler olarak; Türkçe ve Fen Bilimleri 
derslerinden aldığı puanlar ise bağımlı değişken olarak değerlendirilmiştir. Bu değişkenler arasındaki ilişkiyi belirlemek için Kruskal Wallis H-Testi uygulanmıştır.

Anketin 5. maddesine göre, öğrenci ailelerinin \%29,8’i 1-2 odalı dairelerde, \%57,8’i 3 odalı dairelerde, 12,4'ü, 4 ve üstü odalı dairelerde ikamet etmektedir. Anketin 6. maddesine göre, öğrencilerin \%44,4'ü 0-1 arası kardeşe, \%40,7'si 2-3 arası kardeşe, \%14,9'u ise 4 ve üstü kardeșe sahiptir. Anketin 7. maddesi, öğrencilerin bir dönem boyunca okuduğu kitap sayısını göstermektedir. Buna göre öğrencilerin \%36,6's1 4 ay ve üstü 1 kitap okumaktadır veya hiç kitap okumamaktadır. Hiç kitap okumayan öğrenci sayısı çok az olduğu için 4 ay ve üstü seçeneğine eklenmiştir. Öğrencilerin $\% 38,1$ 'i 2-3 ayda bir kitap, \%25,3’ü ayda 1 kitap okumuştur.

Tabloya göre, öğrencilerin Türkçe ve Fen Bilimleri derslerinden aldığı puan değişkenleri ile oda sayısı değişkeni arasında anlamlı $(\mathrm{p}=238 ; 445>0,05)$ bir farkın bulunmadığı görülmektedir. 6 ve 7. maddelerdeki kardeş sayısı ve kitap okuma değişkenleri ile Türkçe ve Fen Bilimleri puan değişkenleri arasındaki fark ise oldukça anlamlıdır $(\mathrm{p}=0,000<0,05)$. 6. maddede kardeş sayısı arttıça öğrencilerin Türkçe ve Fen Bilimleri derslerinden aldıkları puanlar belirgin bir biçimde düşmüştür. Öğrencilerin bir dönem boyunca okuduğu kitap sayısı arttıkça ilgili derslerdeki başarı düzeyleri de yükselmiştir. Öğrencilerin kardeş sayısıyla Türkçe ve Fen Bilimlerindeki başarı düzeyleri ters orantılı iken, kitap okuma durumları ile ilgili derslerdeki başarı düzeyleri arasındaki ilişki ise doğru orantılıdır. Öğrencilerin kitap okuma durumları ile öğrencilerin her iki dersteki başarı düzeyleri arasında güçlü bir ilişki bulunmaktadır. 
Tablo 4: Öğrencilerin sosyoekonomik durumları ile Türkçe ve Fen Bilimleri puanlarına ilişkin Kruskal Wallis H-Testi II

\begin{tabular}{|c|c|c|c|c|c|c|c|}
\hline \multirow{4}{*}{$\begin{array}{l}\text { Türkçe } \\
\text { puanları }\end{array}$} & & & $\mathrm{N}$ & $\%$ & $\bar{X}$ & $\begin{array}{l}\text { Kruskal } \\
\text { Wallis H-Testi }\end{array}$ & $\mathrm{P}$ \\
\hline & 寻 & 1 & 154 & 38,9 & 180,96 & \multirow[t]{3}{*}{$X^{2}: 14,132$} & \multirow[t]{3}{*}{,001 } \\
\hline & $\begin{array}{l}: 0 \\
\mp\end{array}$ & 2 & 196 & 49,5 & 200,76 & & \\
\hline & $\frac{\overline{0}}{0}$ & 3 & 46 & 11,6 & 247,62 & & \\
\hline \multirow{3}{*}{$\begin{array}{l}\text { Fen Bilimleri } \\
\text { puanları }\end{array}$} & .ี & 1 & 154 & 38,9 & 187,96 & \multirow[t]{3}{*}{$X^{2}: 5,916$} & \multirow[t]{3}{*}{, 052} \\
\hline & $\stackrel{\bar{D}}{\vec{\Delta} .0} \Xi$ & 2 & 196 & 49,5 & 199,19 & & \\
\hline & $\infty \vec{z}$ & 3 & 46 & 11,6 & 230,87 & & \\
\hline \multirow{3}{*}{$\begin{array}{l}\text { Türkçe } \\
\text { puanları } \\
\text { Bilimleri } \\
\text { puanları }\end{array}$} & \multirow{6}{*}{ 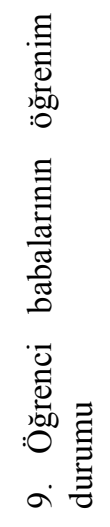 } & 1 & 94 & 23,7 & 170,20 & \multirow[t]{3}{*}{$X^{2}: 18,933$} & \multirow[t]{3}{*}{,000 } \\
\hline & & 2 & 161 & 40,7 & 189,07 & & \\
\hline & & 3 & 141 & 35,6 & 228,14 & & \\
\hline \multirow{3}{*}{$\begin{array}{l}\text { Fen Bilimleri } \\
\text { puanları }\end{array}$} & & 1 & 94 & 23,7 & 172,48 & \multirow{3}{*}{$\begin{array}{l}X^{2}: 17,259 \\
\text { sd: } 2\end{array}$} & \multirow[t]{3}{*}{, 000} \\
\hline & & 2 & 161 & 40,7 & 188,95 & & \\
\hline & & 3 & 141 & 35,6 & 226,75 & & \\
\hline \multirow{3}{*}{$\begin{array}{l}\text { Türkçe } \\
\text { puanları }\end{array}$} & \multirow{6}{*}{ 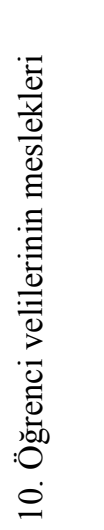 } & 1 & 136 & 34,3 & 175,58 & \multirow[t]{3}{*}{$X^{2}: 15,912$} & \multirow[t]{3}{*}{,000 } \\
\hline & & 2 & 100 & 25,3 & 231,34 & & \\
\hline & & 3 & 160 & 40,4 & 197,46 & & \\
\hline \multirow{3}{*}{$\begin{array}{l}\text { Fen Bilimleri } \\
\text { puanları }\end{array}$} & & 1 & 136 & 34,3 & 182,99 & \multirow{3}{*}{$\begin{array}{l}\mathrm{X}^{2}: 11,323 \\
\text { sd: } 2\end{array}$} & \multirow[t]{3}{*}{,003 } \\
\hline & & 2 & 100 & 25,3 & 228,15 & & \\
\hline & & 3 & 160 & 40,4 & 193,16 & & \\
\hline Toplam & & & 396 & 100,0 & & & \\
\hline
\end{tabular}

Tablo 4'e göre öğrenci anne ve babalarının öğrenim durumlarıyla öğrenci velilerinin meslekleri bağımsız değişkenler olarak, öğrencilerin Türkçe ve Fen Bilimleri derslerinden 
aldıkları puanlar ise bağımlı değişken olarak değerlendirilmiştir. Bu değişkenler arasındaki ilişkiyi belirlemek için ise Kruskal Wallis H-Testi uygulanmıştır.

Tabloya göre öğrenci annelerinin \%38,9’u okur-yazar değil veya ilkokul düzeyinde eğitim almıştır, \%49,5'i ortaokuldan mezun olmuştur. Öğrenci annelerinin \%11,6'sı ise lise ve üniversite düzeyinde öğrenim görmüştür. Öğrenci babalarının öğrenim durumları ise okuryazar değil veya ilkokul \%23,7, ortaokul mezunu \% 40,7, lise ve üniversite mezunu ise \%35,6’dır. Öğrenci velilerinin meslekleri maddesindeki frekans dağılım \%34,3’ü işsiz, çiftçi ve işçi, \% 25,3’ü memur, \%40,4’ü esnaf, serbest meslek ve diğeri şeklindedir.

Tabloya göre, öğrenci annelerinin öğrenim durumları ile öğrencilerin Fen Bilimleri derslerinden aldıkları puan değişkeni arasında anlamlı $(\mathrm{p}=0,052>0,05)$ bir fark bulunmazken, öğrencilerin Türkçe puanları ile annelerin öğrenim durumları değişkenlerinin manidar $(\mathrm{p}=0,01<0,05)$ düzeyde farklı olduğu görülmektedir. 9. ve 10. maddelerdeki öğrenci babalarının öğrenim durumları ve velilerin meslekleri değişkenleri ile Türkçe ve Fen Bilimleri puanları değişkenleri arasındaki fark p=0,00 ile 0,03 şeklinde olup anlamlıdır.

$\mathrm{Bu}$ bulgulara göre öğrenci velilerinin öğrenim düzeyleri ile mesleki seviyeleri yükseldikçe; öğrencilerin Türkçe ve Fen Bilimleri puanları da belirgin bir biçimde artmıştır. 
Tablo 5: Öğrenci ailelerinin gelir durumları ile Türkçe ve Fen Bilimleri puanlarına ilişkin Kruskal Wallis H-Testi

\begin{tabular}{|c|c|c|c|c|c|c|c|}
\hline \multirow{4}{*}{ Türkçe puanları } & & & $\mathrm{N}$ & $\%$ & $\bar{X}$ & $\begin{array}{l}\text { Kruskal } \\
\text { Wallis H-Testi }\end{array}$ & $\mathrm{P}$ \\
\hline & $\stackrel{\Xi}{\Xi}$ & 1 & 125 & 31,6 & 170,32 & \multirow[t]{3}{*}{$X^{2}: 27,879$} & \multirow[t]{3}{*}{, 000} \\
\hline & \multirow{5}{*}{ 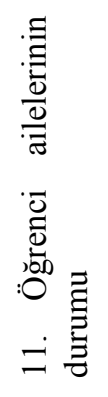 } & 2 & 174 & 43,9 & 192,83 & & \\
\hline & & 3 & 97 & 24,5 & 244,98 & & \\
\hline \multirow{3}{*}{$\begin{array}{l}\text { Fen Bilimleri } \\
\text { puanları }\end{array}$} & & 1 & 125 & 31,6 & 168,39 & \multirow[t]{3}{*}{$X^{2}: 28,020$} & \multirow[t]{3}{*}{, 000} \\
\hline & & 2 & 174 & 43,9 & 195,16 & & \\
\hline & & 3 & 97 & 24,5 & 243,28 & & \\
\hline Toplam & & & 396 & 100,0 & & & \\
\hline
\end{tabular}

Tablo 5'e göre, öğrenci ailelerinin gelir durumları bağımsız, öğrencilerin Türkçe ve Fen Bilimleri derslerinden aldıkları puanlar ise bağımlı değişken olarak değerlendirilmiştir. Değişkenler arasındaki ilişkiyi belirlemek için ise Kruskal Wallis H-Testi uygulanmıştır.

Yukarıdaki tabloya göre öğrenci ailelerinin \%31,6'sı düşük, \%43,9'i orta, \%24,5'i ise yüksek düzeyde bir gelire sahiptir. Değişkenler arasındaki fark yüksek gelirli aile mensubu öğrencilerin lehine $\mathrm{p}=0,00$ düzeyinde anlamlıdır.

Bu bulgulara göre öğrenci velilerinin gelir düzeyleri yükseldikçe, öğrencilerin Türkçe ve Fen Bilimleri derslerinden aldıkları puanlar da belirgin bir biçimde artmıştır. 
Tablo 6: Öğrenci Türkçe ve Fen Bilimleri puanlarına ilişkin korelasyon testi sonuçları

Spearman's rho

Fen Bilimleri

Fen Bilimleri puanları

\begin{tabular}{|c|c|c|c|c|}
\hline & $\begin{array}{l}\text { Fen } \\
\text { Bilimleri }\end{array}$ & Türkçe & $\begin{array}{l}\text { Kruskal } \\
\text { Wallis H-Testi }\end{array}$ & $\mathrm{P}$ \\
\hline korelasyon & 1,000 & $0,707(* *)$ & \multirow{3}{*}{$\begin{array}{l}\text { X2 : } 27,879 \\
\text { sd: } 2\end{array}$} & \multirow[t]{3}{*}{,000 } \\
\hline $\mathrm{P}$ & & ,000 & & \\
\hline $\mathrm{N}$ & 396 & 396 & & \\
\hline Korelasyon & $0,707(* *)$ & 1,000 & \multirow{3}{*}{$\begin{array}{l}\mathrm{X} 2: 28,020 \\
\text { sd: } 2\end{array}$} & \multirow[t]{3}{*}{, 000} \\
\hline $\mathrm{P}$ & ,000 & & & \\
\hline $\mathrm{N}$ & 396 & 396 & & \\
\hline
\end{tabular}

Tablo 6’ya göre öğrencilerin Türkçe dersi ile Fen Bilimleri dersindeki akademik başarıları 0,01 düzeyinde pozitif yönde anlamlıdır. Öğrencilerin her iki dersteki akademik başarılarının korelasyon kat sayısı $(0,707)$ oldukça yüksektir. Yani Türkçe dersinde başarılı olan öğrenciler aynı zamanda Fen Bilimleri dersinde de başarılıdır.

Tablo 7 Öğrencilerin Türkçe ve Fen Bilimleri derslerinden aldıkları puanların dağılımı

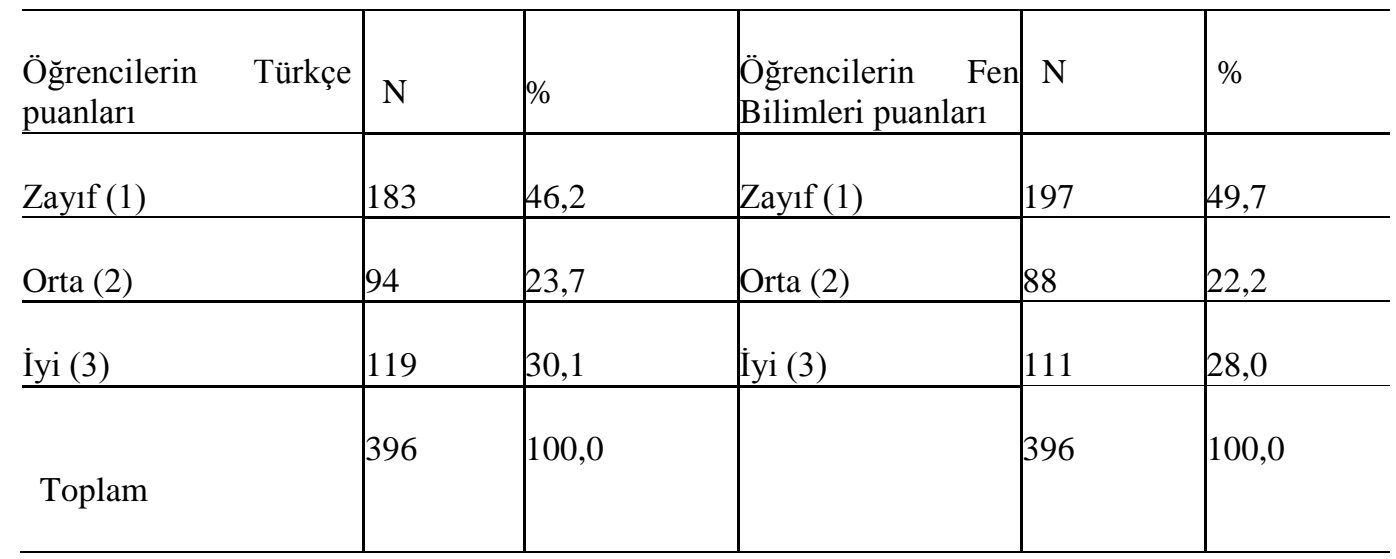

Yukarıdaki tabloya göre öğrencilerin \%46,2'si Türkçe dersinden, \%49,7'si ise Fen Bilimleri dersinden zayıf düzeyde puan almıştır, geriye kalan öğrenciler ise bu derslerden orta ve iyi düzeyde puanlar almıştır. 


\section{Tartışma ve Sonuç}

Bu çalışmada özetle şu sonuçlara ulaşılmıştır: Araştırmada ana sınıfına ve dershaneye giden veya özel bir kursa devam eden öğrencilerin, gitmeyen öğrencilere göre Türkçe ve Fen Bilimleri derslerinde daha başarılı oldukları sonucuna ulaşılmıştır. Aynı şekilde bir bilgisayara sahip olan öğrencilerin sahip olmayanlara göre ilgili derslerde akademik olarak daha başarılı oldukları tespit edilmiştir.

Köse'nin (2007: 61) araştırmasına göre, dershaneye giden öğrencilerin TürkçeMatematik başarı ortalaması 357,89 iken, devam etmeyen öğrencilerin Türkçe-Matematik başarı ortalaması 291,26 puan düzeyindedir. Dolayısı ile üniversiteye giriş sınavlarına hazırlanmak için, dershaneye giden öğrencilerin, gitmeyenlere göre bu sınavlarda daha başarılı oldukları sonucuna ulaşılmıştır. Araştırmamızda dershaneye veya kursa giden öğrencilerin Türkçe ve Fen Bilimleri derslerinde daha başarılı olduğu sonucuna ulaşılmıştır.

Araştırma sonuçlarına göre, öğrenci ailelerinin yaşadığı evlerdeki oda sayısı ile öğrencilerin Türkçe ve Fen Bilimleri derslerindeki akademik başarıları arasında anlamlı bir ilişki yoktur.

Araştırma sonuçlarına göre, öğrencilerin kardeş sayısı arttıkça, Türkçe ve Fen Bilimleri derslerindeki akademik başarı düzeyleri düşmekte, öğrencilerin kitap okuma durumları arttıkça başarı düzeyleri yükselmektedir. Köse (2007: 63) araştırmasında öğrenci başarısı ile kardeş sayısının fazlalığı arasında negatif bir ilişki tespit etmiştir.

Araştırma sonuçlarına göre, öğrenci annelerinin öğrenim durumları ile öğrencilerin Fen Bilimleri derslerinden aldıkları puan değişkenleri arasında anlamlı bir fark yoktur. Öğrenci annelerinin, öğrencilerin başarıları üzerinde çok fazla etkili olmamaları, onların çok 
az kısmının $(\% 11,6)$ lise ve üniversite mezunu olmaları, en önemlisi genellikle öğrenim düzeyi düşük bireylerin (annelerin) Fen Bilimleri gibi sayısal bir dersten çok fazla anlamamalarıyla açıklanabilir.

Ancak öğrencilerin Türkçe puanlarıyla annelerin öğrenim durumları değişkeni anlamlı $(\mathrm{p}=0,01<0,05)$ bir düzeyde farklıdır. Aynı şekilde 9 . ve 10. maddelerdeki öğrenci babalarının öğrenim durumları ve velilerin meslekleri değişkeni ile Türkçe ve Fen Bilimleri puanları değişkenleri arasındaki fark anlamlı düzeydedir. $\mathrm{Bu}$ bulgular öğrenim düzeyi yüksek ebeveynlerin, öğrencilerin akademik başarılarında etkili olduklarını göstermektedir. Nitekim Koçak, Ergin ve Yalçın (2014: 012) araştırmalarında öğrenim düzeyi yüksek ebeveynlerin, kendi çocuklarının dil gelişiminde etkili oldukları sonucuna ulaşmıştır.

Örneğin, Gelbal (2008: 9) araştırmasında, öğrenci babalarının öğrenim düzeylerinin yüksek olması ile öğrencilerin akademik başarıları arasında olumlu bir ilişkinin bulunduğunu tespit etmiştir. Bu sonuç araştırmamızda elde edilen bulguları destekler niteliktedir. Aynı şekilde Köse'nin (2007: 68) araştırmasına göre, öğrencilerin kardeş sayısı arttıkça, onların akademik olarak başarı düzeyleri düşmüş, öğrenci babalarının öğrenim düzeyleri yükseldikçe öğrencilerin akademik başarıları artmıştır.

Ayrıca Yelgün ve Karaman (2015:261) araştırmalarında öğrenci ailelerinin öğrenim düzeyleri ile öğrencilerin öğrenme başarıları arasında doğrusal bir ilişkinin bulunduğu sonucuna ulaşmışlardır. Koçak, Ergin ve Yalçın (2014:104) da "60-72 aylık çocukların Türkçe dil kullanımı düzeyleri ve etki eden faktörlerin incelenmesi” isimli makalelerinde öğrenci ebeveynlerinin öğrenim düzeyleri ile öğrencilerin dili öğrenme durumları arasında anlamı bir ilişkinin bulunduğunu tespit etmişlerdir. 
$\mathrm{Bu}$ araştırma bulgularına göre öğrenci velilerinin gelir düzeyleri ile öğrencilerin Türkçe ve Fen Bilimleri derslerindeki başarıları arasında bir paralellik söz konusudur.

Abbott ve Fouts'un (2003), "Yapılandırmacı öğretim ve öğrenci başarısı" konulu çalışmalarında, öğrenci başarısı ile ailenin eğitime ayırdığı pay arasında güçlü bir ilişki tespit etmişlerdir.

Araştırmada elde ettiğimiz bulgulara göre, Türkçe dersinde başarılı olan öğrenciler aynı zamanda Fen Bilimleri dersinde de başarılıdır. Albayrak ve Erkal (2003). "Başarıya giden yolda ifade ve beceri derslerinin (Türkçe-Matematik) birlikteliği’” adlı çalışmalarında, öğrencilerin Türkçe ile Matematik derslerindeki akademik başarıları arasında paralellik tespit etmişlerdir.

Kılıçarslan'ın (1997: 107) tez çalışmasında, sosyoekonomik durumu iyi olan çocukların, sosyoekonomik durumu düşük olan çocuklara göre okumaya daha çabuk hazır hale geldiklerini tespit etmiştir.

Erkan (2011: 194) yaptığı çalışmasında üst sosyoekonomik gruptaki çocukların okula hazır bulunuşluk düzeylerinin, alt sosyoekonomik gruptaki çocuklara göre daha yüksek olduğunu bulmuştur.

Göktaş'ın (2010), öğrencilerin okuduğunu anlama becerileri ile Matematik dersi başarıları arasında tespit ettiği yüksek ilişkiye benzer bir ilişki biçimi, bu çalışmamızda Türkçe dersi ile Fen Bilimleri dersi arasında tespit edildi. Kıncal, Ergül ve Timur (2007:161) "Fen bilgisi öğretiminde işbirlikli öğrenme yönteminin öğrenci başarısına etkisi” isimli çalışmalarında ortaokul yedinci sınıflara uyguladığı, "Türkçe Okuduğunu Anlama Testi" sonuçları ile "Fen Bilgisi Başarı Testi” sonuçları arasında pozitif bir ilişki tespit etmişlerdir. 
Beydoğan, (1993), “Öğrencilerin sosyoekonomik durum ile Türkçe dersi başarısı arasındaki ilişki” konulu tez çalışmasında sosyoekonomik bakımından durumu iyi olan öğrencilerin, diğer öğrencilere göre Türkçe dersinde daha başarılı olduklarını tespit etmiştir. Gelbal (2008) ilköğretim sekizinci sınıftaki öğrencilerin Türkçedeki başarı düzeyleri ile sosyoekonomik durumlarını karşılaştırdığı çalışmasında Beydoğan'ın araştırmasında elde ettiği sonuçlara yakın bir sonuç elde etmiştir.

Yıldırım (2006) “Akademik başarının yordayıcısı olarak gündelik sıkıntılar ve sosyal destek" konulu çalışmasında, öğrencilere verilen sosyal desteğin, onların akademik başarısına olumlu katkı sağladığını tespit etmiştir.

"Farklı sosyoekonomik düzeydeki anaokulu çocuklarının okumaya hazır olma durumu" konulu çalışmasında Kıliçarslan (1997), sosyoekonomik durumu iyi olan öğrencilerin ciddi bir sıkıntı yaşamadıklarını, okumayı daha hızlı öğrendiklerini tespit etmiştir.

Çiftçi’nin (2007) yaptığı çalışmada, öğrencilerin sosyoekonomik durumları arttıkça başarı düzeylerinin de arttığı görülmektedir.

Güngör’ün (2009), “İlköğretim 5. sınıf öğrencilerinin kitap okuma alışkanlığı ile Türkçe dersi akademik başarıları arasındaki ilişkinin incelenmesi” konulu çalışması ile Çelenk'in (2003) “Okul, aile işbirliği ile okuduğunu anlama başarısı arasındaki ilişki” isimli araştırması sosyoekonomik olarak durumu iyi olan öğrencilerin, akademik olarak da başarılı olduklarını göstermektedir.

Yukarıda örnek olarak verilen bazı araştırmalarda da görüldüğü üzere, öğrencilerin akademik başarıları ile sosyoekonomik gelişmişlikleri arasında güçlü ilişki bulunmaktadır. 
$\mathrm{Bu}$ araştırma sonuçlarına göre, cinsiyet değişkeni ile oda sayısı değişkeni dışında öğrencilerin sosyoekonomik durumları ile Türkçe ve Fen Bilimleri derslerindeki akademik başarıları arasında anlamlı bir ilişki vardır.

Kişi belli bir kültür düzeyinde eğitildiği için, içinde bulunduğu çevrenin varlığı çok önemlidir. Okuma eğitiminin gelişiminde aile bireylerinin önemli katkısı vardır. Aile içindeki bireylerin kültür düzeyleri, okuma alışkınlıkları çocuk üzerinde etki bırakır (Çiftçi ve Temizyürek 2008). Okuma yazmanın oluşumu ve aile ilişkisi üzerinde bir dizi araştırma yapılmıştır. Günümüzde bu çalışmaların temel ilkesi, ailelerin kim oldukları değil; çocukların eğitiminde neler yapabilecekleri üzerine kuruludur (Akyol, 2005: 16).

Öğrencilerin Türkçe ile Fen Bilimleri derslerindeki akademik başarıları arasında güçlü bir ilişki bulunmaktadır. Öğrenci başarısını bütüncül olarak düşünmek gerekir.

Özel ders alan, okuma alışkanlığı kazanan, ana sınıfına giden öğrenciler Türkçe ve Fen Bilimleri derslerinde diğer öğrencilere göre daha başarılı oldukları anlaşılmaktadır. Eğitimöğretim faaliyetlerinde bu durumların göz önünde bulundurulması ve ona göre gerekli önlemlerin alınması gerekir.

Öğrencilerin kardeş sayılarının azlığı ile Türkçe ve Fen Bilimleri derslerindeki akademik başarıları arasında güç ilişki vardır. Öğrenci ebeveynlerinin gelir düzeylerinin ve öğrenim durumlarının yüksekliği nispetinde, ilgili derslerde öğrencilerin akademik başarıları arasında olumlu yönde ilişki bulunmaktadır

Öğrencilerin Türkçe dersindeki akademik başarıları ile Fen Bilimleri dersindeki akademik başarıları arasında güçlü bir ilişki bulunmaktadır.

Bir yaşantı zenginliği olan sosyoekonomik durumun, okuduğunu anlama becerisi 
üzerinde etkisi olduğu için evlerde yaşatılmayan ortam zenginliği mümkün olduğu kadar okullarda telafi edilmelidir (Çiftçi, 2008).

Araştırma sonuçlarına göre öğrencilerin sosyoekonomik gelişmişliklerinin, Türkçe ve Fen Bilimleri derslerindeki akademik başarıları üzerindeki etkisi yadsınamaz. Dolayısı ile öğrencilerin sosyoekonomik düzeylerinin yükseltilmesi için çaba harcanmalıdır.

\section{Makalenin Bilimdeki Konumu (Yeri)}

Türkçe ve Sosyal Bilimler Eğitimi/ Türkçe Eğitimi Anabilim Dalı ve İlköğretim Bölümü/ Fen Bilgisi Eğitimi Anabilim Dalı

\section{Makalenin Bilimdeki Özgünlüğü}

Alan yazın incelendiğinde, ortaokul yedince sınıflarda, Türkçe ve Fen Bilimleri derslerinde sosyoekonomik durumun öğrenci başarısı üzerindeki etkisi konusunda çalışma yapılmamıştır. Ayrıca, bu çalışmada farklı iki disiplinle ilgili araştırmanın yapılmış olması, bu çalışmayı orijinal kılmaktadır.

\section{Kaynaklar}

Abbott, M. L. \& Fouts, J. T. (2003). Constructivist teaching and student achievement: The results of a school-level classroom observation study in Washington. https://www.spu.edu/orgs/research/ObservationStudy-2-13-03.pdf.

Akyol, H., (2005). Türkçe İlkokuma Yazma Öğretimi, Ankara: PegemA Yayıncılık.

Albayrak, M. ve Erkal, M. (2003). Başarıya giden yolda ifade ve beceri derslerinin (TürkçeMatematik birlikteliği), Milli Ĕgitim Dergisi, 158. 
Beydoğan, H. Ö. (1993). Sosyo-ekonomik ve kültürel yönden avantajlı ve dezavantajlı ilkokul son sınıf öğrencilerinin Türkçe dersi bilişsel hedeflerine ulaşma düzeyi, yayımlanmamış doktora tezi, Atatürk Üniversitesi Sosyal Bil. Enstitüsü, Erzurum.

Çelenk, S. (2003). Okul-aile işbirliği ile okuduğunu anlama başarısı arasındaki ilişki, Hacettepe Üniversitesi Eğitim Fakültesi Dergisi, 24, 33-39.

Çiftçi, Ö. (2007). İlköğretim 5. Sinıf Öğrencilerinin Türkçe Öğretim Programında Belirtilen Okuduğunu Anlamayla İlgili Kazanımlara Ulaşma Düzeyinin Belirlenmesi, yayımlanmamış doktora tezi, Gazi Üniversitesi Eğitim Bilimler Enstitüsü, Ankara.

Çiftçi, Ö., F. Temizyürek (2008). İlköğretim 5. Sınıf Öğrencilerinin Okuduğunu Anlama Becerilerinin Ölçülmesi. Mustafa Kemal Üniversitesi, Sosyal Bilimler Dergisi, C. 5, S. 9: 109-128.

Erkan, S. (2011). Farklı Sosyoekonomik Düzeydeki İlköğretim Birinci Sınıf Öğrencilerinin Okula Hazır Bulunuşluklarının İncelenmesi, Hacettepe Üniversitesi Eğitim Fakültesi Dergisi (H. U. Journal of Education) 40: 186-197 [2011].

Gelbal, S. (2008). Sekizinci sınıf öğrencilerinin sosyoekonomik özelliklerinin Türkçe başarısı üzerinde etkisi, Eğitim ve Bilim Cilt 33, Sayı 150 2008, Vol. 33, No 150.

Göktaş, Ö. (2010). Okuduğunu anlama becerisinin ilköğretim ikinci kademe matematik dersindeki akademik başarıya etkisi, yayımlanmamış yüksek lisans tezi, İnönü Üniversitesi, Malatya.

Güngör, E. (2009). Illköğretim 5. sınıf öğrencilerinin kitap okuma alışkanlı̆̆ ile Türkçe dersi akademik başarıları arasındaki ilişskinin incelenmesi, yayınlanmamış yüksek lisans 
tezi, Adana: Çukurova Üniversitesi Sosyal Bilimler Enstitüsü Sınıf Öğretmenliği Anabilim Dal1.

Güvendir, M. A. (2014). Öğrenci başarılarının belirlenmesi sınavında öğrenci ve okul özelliklerinin Türkçe başarısı ile ilişkisi. Eğitim ve Bilim, 39(172).

http://mevzuat.meb.gov.tr/html/ortaogrkurumyon_0/yonetmelik.pdf, Resmi Gazete Millî Eğitim Bakanlığı Ortaöğretim Kurumları Yönetmeliği 7 Eylül 2013.

http://www.tdk.gov.tr/index.php?option=com_bts\&arama=kelime\&guid=TDK.GTS.52d45e2 1f37446.19819472.

Karasar, N (2014). Bilimsel Araştırma Yöntemi, 26. Basım, Nobel Yayınları, Ankara.

Kessler, G. (1985). Sosyolojiye Başlangıç. (Çev. Z. Fındıkoğlu) İstanbul Üniversitesi, İstanbul.

Kılıçarslan, F. (1997). Farklı sosyoekonomik düzeydeki anaokulu çocuklarının okumaya hazır olma durumu, yayımlanmamış doktora tez, Hacettepe Üniversitesi, Sosyal Bil. Enstitüsü, Ankara.

Kıncal, R. Y., Ergül, R., \& Timur, S. (2007). Fen bilgisi öğretiminde işbirlikli öğrenme yönteminin öğrenci başarısına etkisi/ Effect of cooperatıve learnıng method to student achıvement in science teachıng, Hacettepe Üniversitesi Eğitim Fakültesi Dergisi 32 [2007] 156-163.

Kırkkılıç, A. ve Maden, S. (2009). Hızlı okuma için yapılandırıcı bir model önerisi: Hızlı okuma ve anlamı yapılandırma (Prof. Dr. Firdevs güneş). Turkish Studies, 4, 3. 
Koçak, N. Ergin, B. ve Yalçın, H. (2014). 60-72 aylık çocukların Türkçe dil kullanımı düzeyleri ve etki eden faktörlerin incelenmesi, KMÜ Sosyal ve Ekonomik Araştırmalar Dergisi 16 (Özel Sayı II): 100-106, 2014 ISSN: 2147 - 7833, www.kmu.edu.tr

Köse, R. (2007). Aile sosyoekonomik ve demografik özellikleri ile okul ve özel dershanenin liselere giriş sınavına katılan öğrencilerin akademik başarıları üzerindeki etkileri, Ĕ̌itim Bilim Toplum Dergisi 17.5 (2007): 46-77.

Tüzemen,T. ve Kardaş, M.N. (2016). Akademik Çelişki Tekniğinin Öğrencilerin Türkçe Derslerine Yönelik Tutumlarına etkisi ve Bazı Değişkenlerle İlişkisi The Journal of Social Sciences Institute ,p.127-153.

Yazıcıoğlu, Y., \& Erdoğan, S. (2004). SPSS Uygulamalı Bilimsel Araştırma Yöntemleri. Detay Yayınc1lık.

Yelgün, A. \& Karaman, İ. (2015). What Are The Factors Reducing the Academic Achievement in a Primary School Located in a Neighborhood With a Low Socioeconomic Status Egitim ve Bilim, 40(179).

Yıldırım, İ. (2006). Akademik başarının yordayıcısı olarak gündelik sıkıntılar ve sosyal

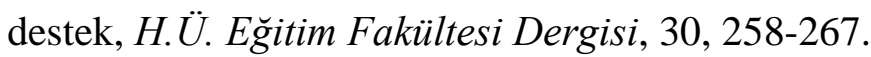

Yılmaz, B. (1995). Ankara'da halk kütüphanesi kullanımı sosyo-ekonomik çözümleme, yayınlanmamış doktora tezi, Hacettepe Üniversitesi, Ankara. 